How to Cite

Pattiasina, V., Latuheru, A., \& Ariani, D. (2019). Auditor skepticism: Papuan case. International Journal of Business, Economics

\& Management, 2(1), 1-10. https://doi.org/10.31295/ijbem.v2n1.46

\title{
Auditor Skepticism: Papuan Case
}

\author{
Victor Pattiasina \\ Universitas Yapis, Papua, Indonesia \\ Corresponding author email: victorpattiasina6@gmail.com
}

\author{
Anita Latuheru \\ STIE Port Numbay, Papua, Indonesia \\ Email: anita.latuheru@ymail.com \\ Dwita Fa'intan Ariani \\ Universitas Yapis, Papua, Indonesia \\ Email: junaidin1@yahoo.com
}

\begin{abstract}
The current research aimed to know the influence of audit's experience, independence, audit's competence, audit's situation, time budget pressure, and gender of the audit's professional skeptic. This research was conducted at the BPKP agency of Papua, Indonesia. The sample was taken using a purposive sampling method with some criteria. The analysis' technic used regression doubled linear analysis. According to the result of the partial test, it was found that independence, the audit's situation, and gender had a positive influence on the audit's professional skeptic. Audit's experience, audit's competence, and time budget pressure did not influence significantly to the audit's professional skeptic.

Keywords---audit experience, audit expertise, audit situation, independence, professional skepticism.
\end{abstract}

\section{Introduction}

Public accountants have the duty to examine and provide opinions on fairness (Yakın \& Erdil, 2012). It must be based on the financial statement of a business entity that is in accordance with the standards determined by the Indonesian Institute of Accountants. In organizations, mostly, management uses the services of an auditor. The auditor is responsible for conducting audits, and evaluates the evidence of activities and economic events related to established criteria, and communicates the results to interested parties therein (Arens et al., 1986; 2008). The preparation of audit reports is the final step in the entire auditing process, as a basis for learning how to collect audit evidence. Chan \& Vasarhelyi (2011) state that auditors must maintain their professional skepticism in order to obtain sufficient evidence or information regarding audit findings.

The phenomenon associated with the skepticism of audit professionals is actually not a new problem (Rasso, 2015). Corless (2009) state that there are several unscrupulous auditors who prioritize personal interests, so they tend to be able to do audit deviations, violations of audit standards as well as auditor's code of ethics (DeFond et al., 1999; $\mathrm{Lu}, 2006$ ). Governor (Papua) Enembe questioned about giving $B P K^{\prime} s^{*}$ Unqualified Opinion to the regional government of Asmat Regency, for the financial statements of the Asmat district from year to year. It has been known that the health condition of residents in Asmat Regency was very sad. Extraordinary events with measles were the problem of malnutrition which has killed dozens of children. In the case, $B P K$ questioned the use of special autonomy funds, which were given to the district (Today, 2018). On this point of view, auditor's professional skepticism has been an important thing to be discussed.

${ }^{*} B P K$ is a legal Indonesian Organization. Its main aim is to examine financial matter. It is also called as State Auditors.

ISSN 2632-9476

Received Jan 20, 2019 / Accepted Jun 18, 2019 / Published Jul 05, 2019 
This study refers to research regarding the factors that influence the auditor's professional skepticism in public accounting firms (Chen et al., 2010). Based on the background description of the problem above, the author intends to conduct research with independent variables namely audit experience, independence, audit expertise, audit situation, time budget pressure, and gender. It seeks to provide further evidence of the influence of audit experience, independence, audit expertise, audit situation, time budget pressure, and gender on the auditor's professional skepticism. The sample was taken from Representative BPK of Papua Province.

\section{Materials and Methods}

\section{Agency Theory}

Jensen; \& Meckling (1976) define agency relations as a contract where one or more owners (principals) hire other people (agents) to do some services for their interests by delegating some decision-making authority to the agent. (Harnowati, 2017) states that the agent, in the employment contract relationship, is morally responsible for maximizing profits principal, but on the other hand, the agent is also interested in maximizing their own welfare.

Next, local government is one type of public sector organization. Its main purpose is to provide public services. (Mardiasmo, 2002) argues that because it involves the use of public money, the government will get pressure from various parties (stakeholders) relating to the need for public accountability. In this case, the auditor acts to evaluate the financial statements prepared by management to be free from misstatements and fraud. If the financial statements prepared by management are far from the problem of fraud, this certainly can benefit both parties.

\section{Cognitive Dissonance Theory}

Dissonance is a feeling of discomfort experienced by someone who can encourage attitudes or behavior to get out of the discomfort. (Mar'at, 1982) states that the condition of cognitive dissonance is a state in which there is a psychological imbalance chosen by self-tension which seeks to achieve balance again. Dissonance means "unbalance" while consonant means "balanced".

(Robbins \& Judge, 2008) reveal that the theory of cognitive nonconformity can help predicting trends in attitudes and behavior of auditors in conducting audit assignments. Cognitive dissonance theory can help explaining the interaction effect between auditor professional skepticism and the factors that influence it. Following is the figure that describes the model of the current research.

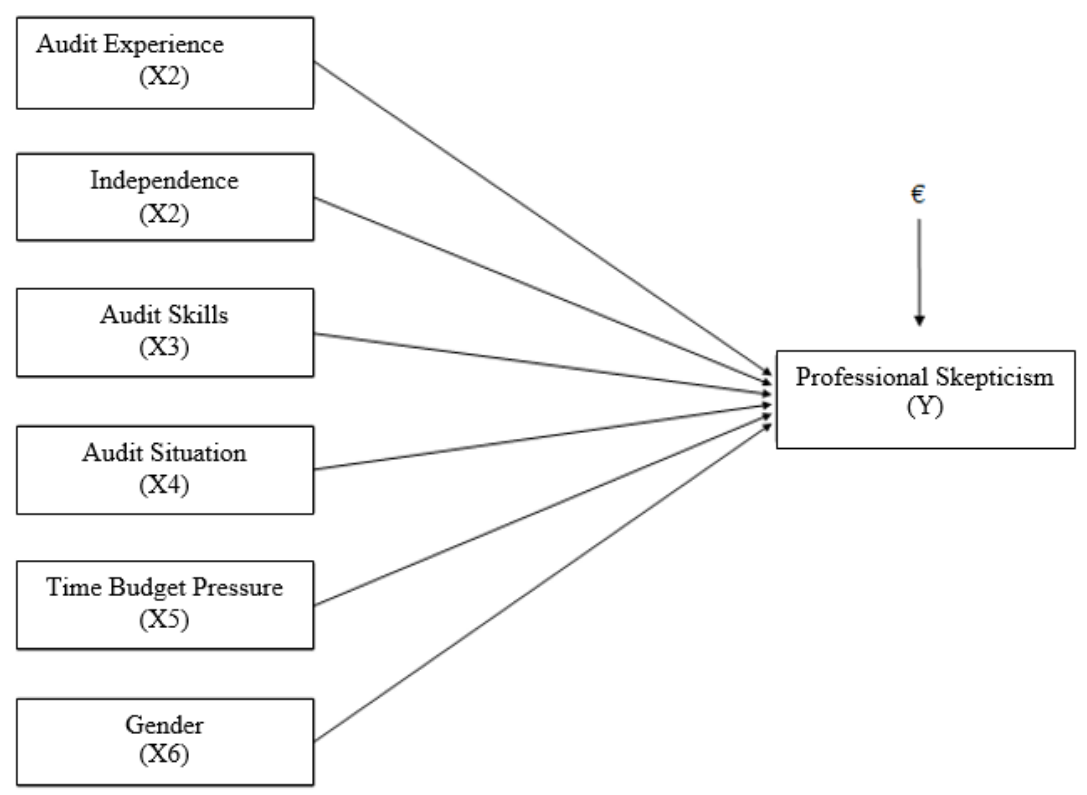

Figure 1. Research model 


\section{Results and Discussions}

The current research applied descriptive statistics. Descriptive statistics are statistics used to analyze data by describing the data without intending to make conclusions that apply to general or generalizations (Millstein \& Maya, 2001). The analysis, which is applied in the current research, is presented as follows.

\section{Validation Test Results}

It is a measure that shows the validity of a questionnaire. The validity test used in this study uses a comparison between the correlation indexes with a significant 5\%. Table 1 shows the results of the validity test using IBM SPSS Statistics 21 for Windows.

Table 1

Test Results for Validity

\begin{tabular}{|c|c|c|c|c|}
\hline \multirow{2}{*}{ Variables } & \multirow{2}{*}{ Item } & \multicolumn{3}{|c|}{ Statement of Correlation Product Moment } \\
\hline & & $\mathrm{R}$ & Sig & Description \\
\hline \multirow{3}{*}{ Audit Experience (AE) } & $\mathrm{AE}_{1}$ & 0,640 & 0,000 & Valid \\
\hline & $\mathrm{AE}_{2}$ & 0,769 & 0,000 & Valid \\
\hline & $\mathrm{AE}_{3}$ & 0,773 & 0,000 & Valid \\
\hline \multirow{10}{*}{ Independent (I) } & $\mathrm{AE}_{4}$ & 0,709 & 0,000 & Valid \\
\hline & $\mathrm{AE}_{5}$ & 0,668 & 0,000 & Valid \\
\hline & $\mathrm{AE}_{6}$ & 0,653 & 0,000 & Valid \\
\hline & $\mathrm{I}_{1}$ & 0.737 & 0.000 & Valid \\
\hline & $\mathrm{I}_{2}$ & 0.746 & 0.000 & Valid \\
\hline & $\mathrm{I}_{3}$ & 0.667 & 0.000 & Valid \\
\hline & $\mathrm{I}_{4}$ & 0.651 & 0.000 & Valid \\
\hline & $\mathrm{I}_{5}$ & 0.682 & 0.000 & Valid \\
\hline & $I_{6}$ & 0.733 & 0.000 & Valid \\
\hline & $\mathrm{I}_{7}$ & 0.827 & 0.000 & Valid \\
\hline \multirow{3}{*}{ Audit Skills (ASs) } & $\mathrm{ASs}_{1}$ & 0.688 & 0.000 & Valid \\
\hline & $\mathrm{ASs}_{2}$ & 0.754 & 0.000 & Valid \\
\hline & $\mathrm{ASs}_{3}$ & 0.729 & 0.000 & Valid \\
\hline \multirow{5}{*}{ Audit Situation (AS) } & $\mathrm{ASs}_{4}$ & 0.768 & 0.000 & Valid \\
\hline & $\mathrm{ASs}_{5}$ & 0.719 & 0.000 & Valid \\
\hline & $\mathrm{AS}_{1}$ & 0.892 & 0.000 & Valid \\
\hline & $\mathrm{AS}_{2}$ & 0.930 & 0.000 & Valid \\
\hline & $\mathrm{AS}_{3}$ & 0.941 & 0.000 & Valid \\
\hline \multirow[b]{2}{*}{ Time Budget Pressure (TBP) } & $\mathrm{TBP}_{1}$ & 0,759 & 0,000 & Valid \\
\hline & $\mathrm{TBP}_{2}$ & 0,759 & 0,000 & Valid \\
\hline
\end{tabular}




\begin{tabular}{lcccc}
\hline & $\mathrm{TBP}_{3}$ & 0,720 & 0,000 & Valid \\
& $\mathrm{TBP}_{4}$ & 0,698 & 0,000 & Valid \\
& $\mathrm{G}_{1}$ & 0,858 & 0,000 & Valid \\
Gender $(\mathrm{G})$ & $\mathrm{G}_{2}$ & 0,799 & 0,000 & Valid \\
& $\mathrm{G}_{3}$ & 0,674 & 0,000 & Valid \\
& $\mathrm{G}_{4}$ & 0,833 & 0,000 & Valid \\
& $\mathrm{G}_{5}$ & 0,798 & 0,000 & Valid \\
& $\mathrm{PSA}_{1}$ & 0.855 & 0.000 & Valid \\
& $\mathrm{PSA}_{2}$ & 0.757 & 0.000 & Valid \\
& $\mathrm{PSA}_{3}$ & 0.862 & 0.000 & Invalid \\
& $\mathrm{PSA}_{4}$ & 0.760 & 0.000 & Valid \\
& $\mathrm{PSA}_{5}$ & 0.810 & 0.000 & Valid \\
& $\mathrm{PSA}_{6}$ & 0.877 & 0.000 & Valid \\
\hline
\end{tabular}

\section{Reliability Test Results}

Instrument reliability is the result of reliable measurements. Instrument reliability is used to obtain data based on measurement objectives. To test reliability in this study using coefficient Cronbach's Alpha Based on Standardized Items. A variable is said to be reliable if the alpha value is > 0.7 (Ghozali, 2018).

Table 2

Reliability Test Results

\begin{tabular}{clcc}
\hline No. & \multicolumn{1}{c}{ Variable } & Cronbach's Alpha Based on Standardized Items & Information \\
\hline 1. & Audit Experience (AE) & 0.800 & Reliable \\
2. & Independence (I) & 0.849 & Reliable \\
3. & Audit Skills (ASs) & 0.798 & Reliable \\
4. & Audit Situation (AS) & 0.910 & Reliable \\
5. & Time Budget Pressure (TBP) & 0.716 & Reliable \\
6. & Gender (G) & 0.856 & Reliable \\
7. & Professional Skepticism Audit (SPA) & 0.903 & Reliable \\
\hline
\end{tabular}

Based on Table 2 indicates that the value of Cronbach's alpha based on standardized variables for audit experience, independent variables, audit expertise variables, audit situation variables, time budget pressure variables, variables gender, and professional audit skepticism variables indicate that the value of Cronbach's alpha based on standardized above 0.7 which means that the question construct in the seven variables is reliable. 
Normality Test

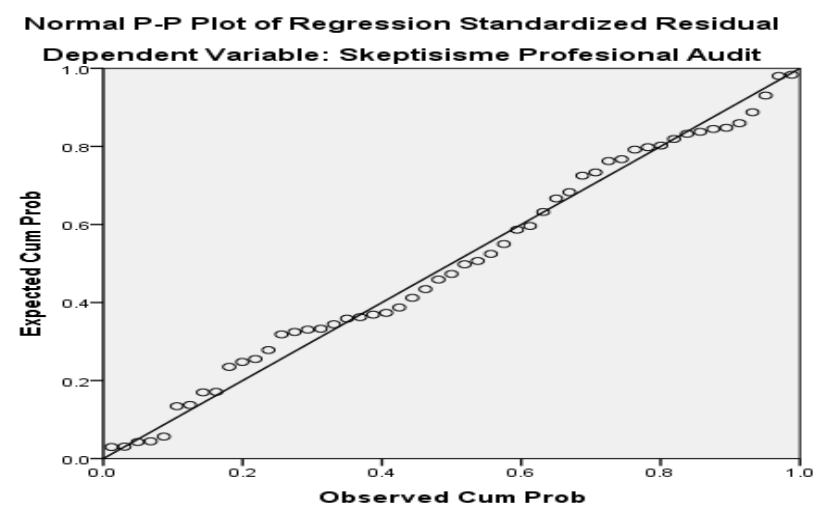

Figure 2. Normality Test Results

From the results of the graph above, it can be seen that the points spread around the diagonal line and its distribution follow the direction of the diagonal line, the data shows that experience variable, independence variables, audit expertise variables, audit situation variables, time budget pressure variables, gender variables and professional skepticism variables normally distributed audit.

Table 3

Normality Testing

\begin{tabular}{|c|c|c|}
\hline \multicolumn{3}{|c|}{ Results of the Normality Testing of the One-Sample Kolmogorov-Smirnov Test } \\
\hline \multicolumn{3}{|c|}{ Unstandardized Residual } \\
\hline $\mathrm{N}$ & & 53 \\
\hline \multirow[t]{2}{*}{ Normal Parameter a, b } & Mean &, 0000000 \\
\hline & Std. Deviation & 2,68875158 \\
\hline \multirow[t]{3}{*}{ Most Extreme Differences } & Absolute &, 067 \\
\hline & Positive &, 050 \\
\hline & Negative & -067 \\
\hline \multicolumn{2}{|l|}{ Kolmogorov-Smirnov Z } & ,487 \\
\hline \multicolumn{2}{|l|}{ A Symp. Sig. (2-tailed) } & , 972 \\
\hline \multicolumn{3}{|c|}{ a. The distribution test is Normal. } \\
\hline b. Calculated from data. & & \\
\hline
\end{tabular}

Based on Table 3, the magnitude of the Kolmogorov-Smirnov value is 0.487 with a significance value of 0.972 and a $\alpha$ value above 5\% (0.05). This means that data is normally distributed, or the data is stated to meet the assumption of normality.

\section{Multicollinearity Test Results}

Multicollinearity test aims to test whether there is a strong correlation or relationship between independent variables in a multiple linear regression model. 
Table 4

Multicollinearity Test Results

\begin{tabular}{llll}
\hline \multirow{2}{*}{ Model } & \multicolumn{3}{c}{ Coefficients } \\
\hline & Tolerance of & \\
(Constant) & VIF & & \\
& & & Information \\
Audit Experience &, 806 & 1,241 & $\begin{array}{l}\text { Not occurrence of } \\
\text { multicollinearity }\end{array}$ \\
Independent &, 639 & 1,566 & Not multicollinearity \\
of audit expertise &, 773 & 1,293 & Not multicollinearity \\
Audit situation &, 699 & 1,431 & No multicollinearity \\
Time Budget Pressure &, 811 & 1,233 & Multicollinearity \\
Gender &, 936 & 1,068 & No multicollinearity
\end{tabular}

Based on Table 4, the value tolerance for each variable has a cut-off value above 0.1. VIF (Variance Inflating Factor) and each variable also have a value above 10 . So it can be concluded that in the multicollinearity test there is no correlation between each independent variable.

\section{Heteroscedasticity Test Results}

If there is no clear pattern and the points spread above and below the number 0 on the Y-axis, there will be no heteroscedasticity (Ghozali, 2016). A good regression model is a model that does not experience heteroscedasticity.

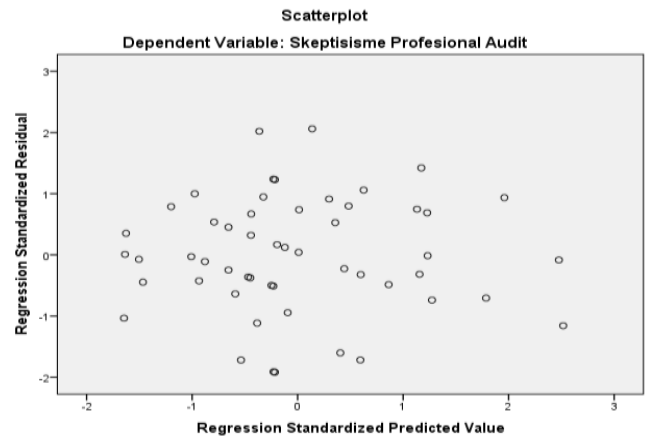

Figure 3. Heteroscedasticity test

Based on Figure 3, the scatterplots graph shows that the points spread randomly, do not have a regular pattern, and are spread well above and below the number 0 on the $\mathrm{Y}$-axis. Based on these results, it can be concluded that heteroscedasticity does not occur in the regression model, so the regression model is feasible used to predict auditor professional skepticism based on the independent variable of audit experience, independence, audit expertise, audit situation, time budget pressure, and gender. 
Multiple Linear Regression Test Results

The test results of multiple linear regression are presented in the following table.

Table 5

Multiple Linear Regression Test Results

\begin{tabular}{|c|c|c|c|c|c|c|c|c|}
\hline \multicolumn{9}{|c|}{ Coefficients ${ }^{a}$} \\
\hline \multicolumn{2}{|c|}{ Model } & \multicolumn{2}{|l|}{$\begin{array}{l}\text { Unstandardized } \\
\text { Coefficients }\end{array}$} & \multirow{2}{*}{$\begin{array}{l}\text { Standardized } \\
\text { Coefficients } \\
\text { Beta }\end{array}$} & \multirow[t]{2}{*}{$\mathrm{t}$} & \multirow[t]{2}{*}{ Sig. } & \multicolumn{2}{|l|}{$\begin{array}{l}\text { Collinearity } \\
\text { Statistics }\end{array}$} \\
\hline & & B & Std. Error & & & & Tolerance & VIF \\
\hline 1 & (Constant) & 11252 & 6045 & & 1,861 & .069 & & \\
\hline & Audit experience & -.049 & .150 & -.045 & -.328 & .745 & .806 & 1,241 \\
\hline & independency & .163 .444 .006 & .639 & & 2,877 & & .469 & 1,566 \\
\hline & Audit Expertise & -.270 & .137 & -.276 & -1971 & .055 & .773 & 1293 \\
\hline & Audit Situations & .399 & .157 & .375 & 2,542 & .014 & 699 & 1,431 \\
\hline & $\begin{array}{l}\text { Time Budget } \\
\text { Pressure }\end{array}$ & .168 & .189 & .122 & .891 & .378 & .811 & 1,233 \\
\hline & Gender & $-2,375$ & $.970-$ & 312 & $-2,449$ & .018 & .936 & 1,068 \\
\hline
\end{tabular}

a. Dependent Variable: Professional Audit Skepticism

Based on the results of Table 5, the linear regression equation is obtained as follows. PSA $=11,581-0,078 \mathrm{AE}+$ $0.480 \mathrm{I}-0.257 \mathrm{ASs}+0.390 \mathrm{AS}+0.154 \mathrm{TBP}-2.317 \mathrm{G}+\mathrm{e}$. The multiple linear regression equation above can be interpreted that:

1) Constant Regression $(\alpha)=11.252$

The constant of 11.252 states that the professional audit skepticism variable in Papua Province BPPP office is equal to 11.252 .

2) Audit Experience Regression Coefficient (AE)

Regression coefficient PA is -0.049 . This means that whenever there is an increase in one level of audit experience, it will reduce one level of audit professional skepticism by 0.049 or $4.9 \%$.

3) Independent Regression Coefficient (I)

Regression coefficient I is 0.469 . This means that whenever there is an increase in one level of independence, it will increase the auditor's level of professional skepticism by 0.469 or $46.9 \%$.

4) Audit Expertise Regression Coefficient (ASs)

Regression coefficient (ASs) is worth -0.270 . This shows that whenever there is an increase in one audit skill level, it will reduce one level of audit professional skepticism by 0.270 or $27 \%$.

5) Audit Situation Regression Coefficient (AS)

The SA regression coefficient is 0.399 . This means that whenever there is an increase in one level of the audit situation, it will increase one auditor's level of professional skepticism by 0.399 or $39.9 \%$ without other factors being affected. 
6) Regression Coefficients Time Budget Pressure (TBP)

TBP regression coefficient is 0.168 . This means that whenever there is an increase in one level of variable time budget pressure, it will increase the auditor's level of professional skepticism by 0.168 or by $16.8 \%$.

7) Regression Coefficient Gender (G)

The regression coefficient $G$ which is $-2,375$. The coefficient is negative, meaning that there is a negative relationship between the variable gender and the audit professional skepticism, namely the variable gender can reduce the value of the audit professional skepticism variable by 2,375 or $237.5 \%$.

\section{Partial Test Results ( $t$-Test)}

The t-test is used to find out whether each independent variable has an influence on the dependent variable by considering a significant level of 0.05 , and by using the SPSS 21 program application in the following table.

Table 6

Partial Test Results (Test t)

\begin{tabular}{llllll}
\hline \multicolumn{7}{c}{ Coefficients } \\
\hline Model & \multicolumn{7}{c}{ Unstandardized Coefficients } & Standardized Coefficients & T & Sig. \\
& B & Std. Error & Beta & & \\
$1 \quad$ (Constant) & 11.252 & 6.045 & & 1,861 &, 069 \\
Audit Experience & -049 &, 150 & -045 & -328 &, 745 \\
Independent &, 469 &, 163 &, 444 & 2,877 & 006 \\
Audit Expertise &,- 270 &, 137 &,- 276 & $-1,971$ &, 055 \\
Audit Situation &, 399 &, 157 &, 375 & 2,542 &, 014 \\
Time Budget Pressure &,- 168 &, 189 &,- 122 &, 891 &, 378 \\
Gender & $-2,375$ &, 970 &,- 312 & $-2,449$ &, 018 \\
a. Dependent Variable: Professional Audit Skepticism & & & \\
\hline
\end{tabular}

Based on the results of the regression equation in Table 6 it can be concluded as follows:

1) From the partial test results of the influence of Audit Experience, it can be seen that $t_{\text {count }}$, at $-0,328$ with a significant level of 0.745 , is greater than 0.05 . This shows that $\mathrm{H}_{\mathrm{o}}$ is accepted and $\mathrm{H}_{1}$ is rejected. Audit experience has no effect and is insignificant towards audit professional skepticism, so the first hypothesis is rejected.

2) The partial test of the influence of Independent can be seen that $t_{\text {count }}$ is 2.877 with a significant level of 0.006 , smaller than 0.05. This shows that $\mathrm{H}_{\mathrm{o}}$ is rejected and $\mathrm{H}_{2}$ is accepted. Independent has a significant and significant effect on the skepticism of audit professionals, so the second hypothesis is accepted.

3) The partial test of the influence of Audit Skills can be seen that $t_{\text {count }}$ is -1.971 with a significant level of 0.055 , greater than 0.05 . This shows that $\mathrm{H}_{\mathrm{o}}$ is accepted and $\mathrm{H}_{3}$ is rejected. Audit expertise has no effect and is not significant towards professional audit skepticism, so the third hypothesis is rejected.

4) The partial test of the influence of Audit Situation can be seen that $t_{\text {count }}$ is 2.542 with a significant level of 0.014 , smaller than 0.05. This shows that $\mathrm{H}_{\mathrm{o}}$ is rejected and $\mathrm{H}_{4}$ is accepted. The audit situation has an effect and is significant on the skepticism of audit professionals, so the fourth hypothesis is accepted.

5) The partial test of the effect of Time Budget Pressure can be seen that $t_{\text {count }}$ is 0.891 with a significant level of 0.378 , greater than 0.05. This shows that $\mathrm{H}_{\mathrm{o}}$ is accepted and $\mathrm{H}_{5}$ is rejected. Time budget pressure has no effect and is not significant to audit professional skepticism, so the fifth hypothesis is rejected. 
6) The partial test of the influence of Gender can be seen that $t_{\text {count }}$ is $-2,449$ with a significant level of 0.018 , smaller than 0.05. This shows that $\mathrm{H}_{\mathrm{o}}$ is rejected and $\mathrm{H}_{6}$ is accepted. Gender influences and is significant towards professional audit skepticism, so the sixth hypothesis is accepted.

\section{Determination Coefficient Test Results}

The following table describes the results of determination coefficient test.

Table 7

Test Results of the Determination Coefficient

\begin{tabular}{lllll}
\hline & & \multicolumn{2}{c}{ Summary } \\
\hline Model & $\mathrm{R}$ & R Square & Adjusted R Square & Std. The error of the Estimate \\
\hline 1 & $549^{\mathrm{a}}$ & 301 & 210 & 2.859 \\
\hline
\end{tabular}

a. Predictors: (Constant), Audit Experience, Independence Audit Skills, Audit Situations, Time Budget Pressure and Gender

b. Dependent Variable: Professional Audit Skepticism

Table 7 shows the Adjusted R Square value of 0.210 gives the sense that the variation that occurs in the audit professional skepticism variable is $21 \%$ determined by audit experience variables, independence, audit expertise, audit situation, time budget pressure, and gender. And the rest is 0.79 or $79 \%(100 \%-21 \%)$ explained by other variables not included in this research model

\section{Conclusion}

Based on the results of the analysis carried out on the results of the questionnaire that was distributed at the office of the BPKP Representative of the Papua Province, it can be concluded that independent variables, audit situations, gender positively influence the skepticism of audit professionals. Audit experience, audit expertise, time budget pressure does not affect the skepticism of audit professionals. Simultaneous Testing Results show that the audit experience, independence, audit expertise, audit situation, time budget pressure, and gender influence the skepticism of audit professionals.

\section{Suggestions}

Herewith we suggest some suggestions that based on the results of the current study. The suggestions are given to the future researchers, namely;

1. This study only used six variables; therefore, it is expected that the future researchers may examine other factors that can affect the skepticism of audit professionals in other place of Indonesia, such as the complexity of tasks, ethics, and other variables.

2. This study only used population and samples at the Representative Office of BPKP in Papua Province, Indonesia. It is expected that the future researchers may add more population numbers and samples in the study of audit professional skepticism.

3. This study only used data collection methods through questionnaires. So that it is expected that the future researchers may add other methods of data collection, such as interview methods, etc., in the research that will be conducted. The future researchers are also expected to be able to add other supporting indicators that can measure the experience of the auditors.

\section{Acknowledgments}

This work was supported by the Independent Research Fund. 


\section{References}

Arens, A. A., Elder, R. J., \& Beasley, M. S. (2008). Auditing dan jasa Assurance. Jakarta: Erlangga.

Arens, A. A., \& Loebbecke, J. K. (1986). Auditing: Suatu Pendekatan Terpadu. Erlangga, Jakarta.

Chan, D. Y., \& Vasarhelyi, M. A. (2011). Innovation and practice of continuous auditing. International Journal of Accounting Information Systems, 12(2), 152-160. https://doi.org/10.1016/j.accinf.2011.01.001

Chen, Q., Kelly, K., \& Salterio, S. (2010, October). Do audit actions consistent with increased auditor skepticism deter potential management malfeasance? In CAAA Annual Conference. http://dx.doi.org/10.2139/ssrn.1490123

Corless, J. C. (2009). Fraud awareness of internal auditors. The Journal of Theoretical Accounting Research, 4(2), 93.

DeFond, M. L., Wong, T. J., \& Li, S. (1999). The impact of improved auditor independence on audit market concentration in China. Journal of Accounting and Economics, 28(3), 269-305. https://doi.org/10.1016/S01654101(00)00005-7

Gawronski, B., \& Strack, F. (2004). On the propositional nature of cognitive consistency: Dissonance changes explicit, but not implicit attitudes. Journal of experimental social psychology, 40(4), 535-542. https://doi.org/10.1016/j.jesp.2003.10.005

Ghozali, I. (2018). Aplikasi analisis multivariete dengan program IBM SPSS 23.

Harnowati, A. I. P. (2017). Determinan Pengungkapan Laporan Keuangan Pemerintah Daerah di Indonesia (Doctoral dissertation, Universitas Lampung).

Jensen, M. C., \& Meckling, W. H. (1976). Theory of the firm: Managerial behavior, agency costs and ownership structure. Journal of financial economics, 3(4), 305-360. https://doi.org/10.1016/0304-405X(76)90026-X

$\mathrm{Lu}, \mathrm{T}$. (2006). Does opinion shopping impair auditor independence and audit quality?. Journal of Accounting Research, 44(3), 561-583. https://doi.org /10.1111/j.1475-679X.2006.00211.x

Mar'at. (1982). Sikap Manusia Perubahan Serta Pengukurannya. Jakarta: Ghalia Indonesia.

Mardiasmo, A. (2002). Otonomi dan Manajemen Keuangan Daerah: Good Governance, Democratization, Local Government Financial Management.

Millstein, P., \& Maya, A. (2001). An evaluation of occlusal contact marking indicators: A descriptive quantitative method. The Journal of the American Dental Association, 132(9), 1280-1286.

Rasso, J. T. (2015). Construal instructions and professional skepticism in evaluating complex estimates. Accounting, Organizations and Society, 46, 44-55. https://doi.org/10.1016/j.aos.2015.03.003

Robbins, Stephen P., \& Judge, Imothy A. (2008). Perilaku Organisasi. Jakarta: Salemba Empat.

Today, Papua. (2018). Gubernur Pertanyakan Opini WTP Kabupaten Asmat. https://www.papuatoday.com/2018/01/22/gubernur-pertanyakan-opini-wtp-kabupaten-asmat/

Yakın, M., \& Erdil, O. (2012). Relationships between self-efficacy and work engagement and the effects on job satisfaction: a survey on certified public accountants. Procedia-Social and Behavioral Sciences, 58, 370-378. https://doi.org/10.1016/j.sbspro.2012.09.1013 